\title{
Warm-water events in the eastern Fram Strait during the last 2000 years as revealed by different microfossil groups
}

\author{
Alexander Matul $\oplus^{\mathrm{a}}$, Robert F. Spielhagen ${ }^{\mathrm{b}}$, Galina Kazarina ${ }^{\mathrm{a}}$, Svetlana Kruglikova $\mathbb{(}^{\mathrm{a}}$, Olga Dmitrenko ${ }^{\mathrm{a}}$ \\ \& Rahul Mohan (10)
}

aShirshov Institute of Oceanology, Marine Geology Department, Moscow, Russia; bGEOMAR Helmholtz Centre for Ocean Research, Ocean Circulation and Climate Dynamics Division, Kiel, Germany; 'National Centre for Polar and Ocean Research, Antarctic Science Department, Vasco-da-Gama, India

\begin{abstract}
The environmental system of the northern Nordic Seas is very sensitive to oceanographic and climatic changes at the contact of cold Arctic and warmer North Atlantic waters. These contrasts are reflected in the associations of marine microorganisms and archived in the bottom sediments. A microfossil study (diatoms, coccoliths) of late Holocene sediments in core MSM5/5-712-1 from the eastern Fram Strait provides a better understanding of marine ecosystems and palaeoenvironments during Arctic warming events of the last two millennia. Indicative diatom species and groups of species revealed a high variability of sea-surface conditions. Based on the diatom distribution, three warming periods could be detected, corresponding to the time intervals of 0 to $440 \mathrm{CE}$ (the later part of the Roman Warm Period), 1200 to 1420 CE (the final part of the Medieval Climate Anomaly) and 1730 CE to present (including the Recent Warming). The various micropalaeontological proxies used in this study and other publications describe the Roman Warm Period and, especially, the Recent Warming as the most pronounced warm events in the area during the last 2000 years. A comparison of data from the different microfossil groups, indicators of seasurface and subsurface conditions, reveals variable, complicated and non-simultaneous palaeoenvironmental signals within the warm periods. This can potentially be explained by changes in the surface/subsurface water structure during the events (variations in the cold/ warm water advection, stratification, availability of nutrients, seasonal succession of bioproductivity, etc.), which are reflected by changes in the microplankton communities.
\end{abstract}

\section{KEYWORDS}

Arctic warming; late Holocene;

micropalaeontology; sea surface/subsurface palaeoenvironments

\section{ABBREVIATIONS}

AW: Atlantic Water; BC: before the Christian era; $\mathrm{CE}$ Christian era; DACP: Dark Ages Cold Period; kyr: thousands of years; LIA: Little Ice Age; MCA: Medieval Climate Anomaly; RW: Recent Warming; RWP: Roman Warm Period; SST: sea-surface temperature

\section{Introduction}

Palaeoclimatic studies document a high variability of Arctic environments on multidecadal to centennial timescales during the late Holocene, with prominent coolings and warm anomalies (e.g., Kaufman et al. 2009; Spielhagen et al. 2011). The late Holocene (last ca. 3000-4000 years) in the Northern Hemisphere is described as a period of neoglaciation with a distinct decrease of summer temperatures in the Arctic, Nordic Seas, Fennoscandia, Greenland and Canadian Arctic if compared to the Holocene climatic optimum (Miller et al. 2010; Eldevik et al. 2014; Briner et al. 2016; Sejrup et al. 2016). However, the overall cooling trend was superimposed by the RWP ( $250 \mathrm{BC}$ to $400 \mathrm{CE}$ ), and the warm MCA (950 to 1250 CE) as shown by Mann et al. (2009) for continental northern Europe, and by Eldevik et al. (2014) for the Nordic Seas. The RW started at the end of the 19th century and the last 50 years were the warmest in the northern high-latitude areas within the last two millennia (Kaufman et al. 2009; Miller et al. 2010), being comparable to the mid-Holocene thermal maximum in the Nordic Seas and Fennoscandia (Sejrup et al. 2016).
For the purposes of data presentation and interpretation in this paper, these intervals are referred to, although some developments in our research area seem not in line with the above climatic subdivision.

The warming intervals RWP, MCA, and especially the RW correlate well with events of enhanced transfer of warm subsurface AW from the Norwegian Sea into the Arctic via the eastern Fram Strait (Spielhagen et al. 2011; Werner et al. 2011; Werner et al. 2013; Zamelczyk et al. 2013). Hydrological measurements by moorings in Fram Strait revealed a stable trend of increasing temperature of the AW propagating into the Arctic during the period of 1997-2010, without significant changes in transport volumes (Beszczynska-Möller et al. 2012). In this area, planktic foraminifera are suitable recorders of subsurface oceanic regimes (below $50 \mathrm{~m}$ water depth) that are dominated by AW (Spielhagen et al. 2011). However, the near-surface environments in the uppermost $50 \mathrm{~m}$ can be influenced by several factors, like surface cooling, sea-ice formation and sea-ice coverage, as well as freshwater injections from the continents. 
For the present study, we compiled data from various microfossils groups representing organisms that lived close to the sea surface and whose remains reflect the environmental conditions of their times. The data presented here contribute to a better understanding of late Holocene palaeoceanographic changes near the ocean surface of Fram Strait and how these were related to the detected warm events.

\section{Study area and research strategy}

Our area of study is located in the eastern Fram Strait close to Svalbard (Fig. 1). AW with a core temperature of $2-6^{\circ} \mathrm{C}$ occupies most of the upper ca. $500 \mathrm{~m}$ of the water column in the West Spitsbergen Current (Fig. 2) along the continental margin (Holland et al. 1996; Talley et al. 2011). Summer temperatures in the upper mixed layer of the West Spitsbergen Current may reach $6-8^{\circ} \mathrm{C}$ (Norwegian Polar Institute 2017) at the investigated core site. Winter sea-ice concentrations from February to April of 1976-2006 varied between "open water" and "very open drift ice" or between 0-1/10th and 1-4/10th, respectively (Norwegian Ice Service 2017). The period of highest bioproductivity in the eastern Fram Strait lasts from April to August, peaking in May-July (Cherkasheva et al. 2014). Diatoms (microplankton algae with silica frustules) usually dominate the phytoplankton communities and have their maximum percentages in the total phytoplankton biomass of Fram Strait surface waters at depths of 5-20 m within the summer mixed layer (Kubiszyn et al. 2014). Because of the sensitivity of the

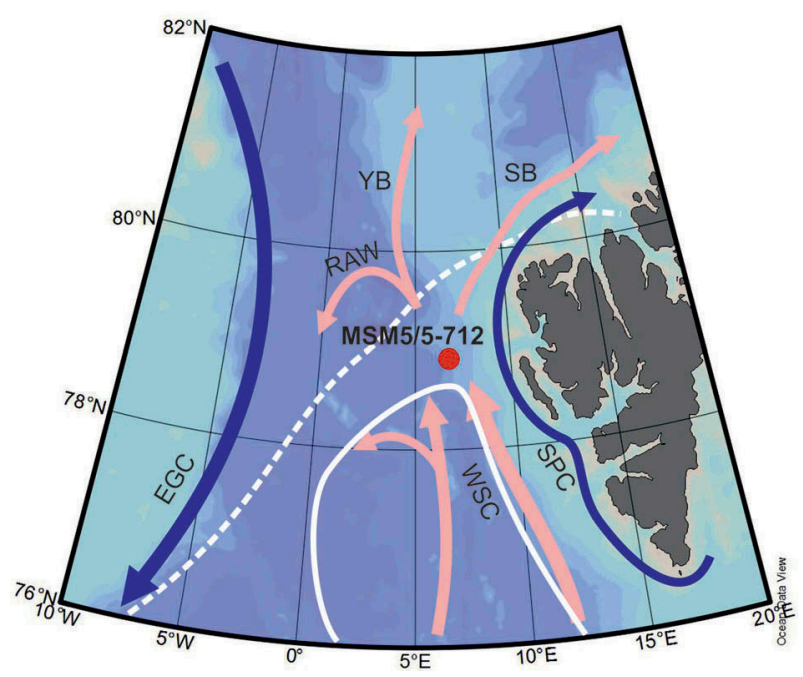

Figure 1. Location of the studied sediment core and oceanographic setting. Water circulation at the sea surface is modified from Marnela et al. (2008) and Nielsen et al. (2016). AW (pink arrows): WSC is West Spitsbergen Current (west and east branches), RAW is Return Atlantic Water, YB is Yermak Branch, SB is Svalbard Branch. Polar Water (blue arrows): SPC is Spitsbergen Polar (Coastal) Current, EGC is East Greenland Current. Average sea-ice limits in 1976-2006 (Norwegian Ice Service 2017): solid white line is for March, dashed white line is for September.

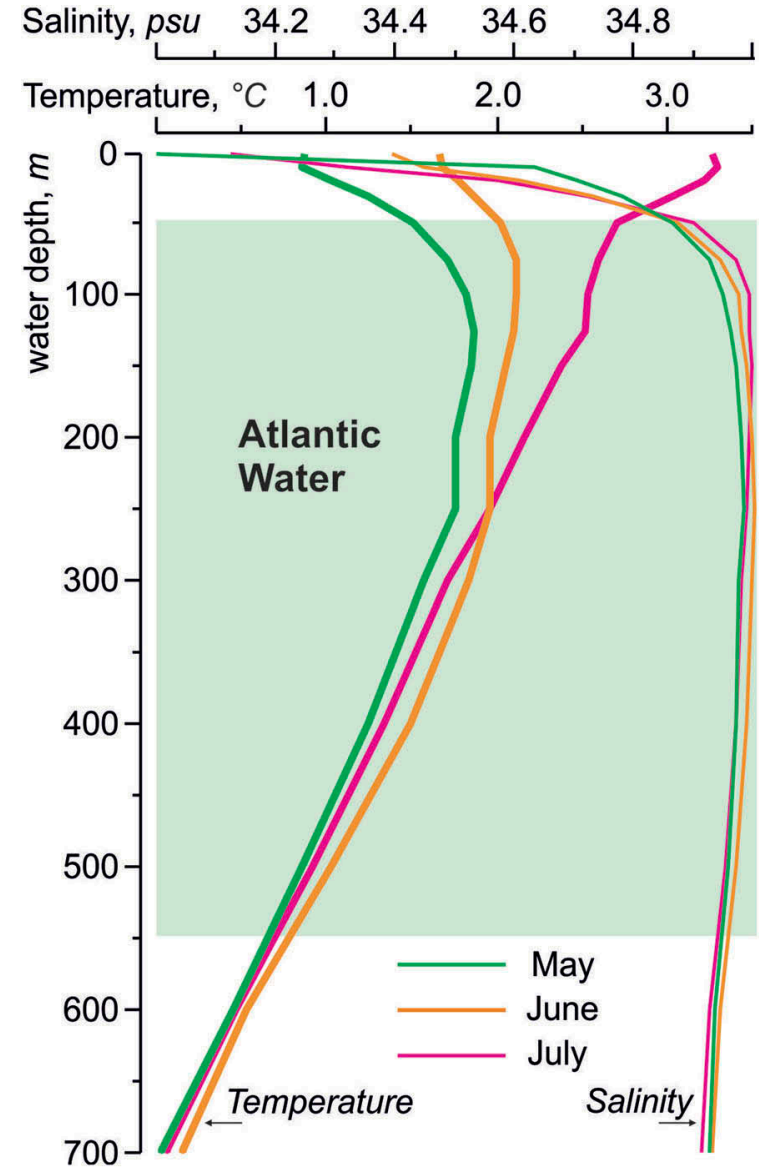

Figure 2. Vertical profiles of average temperature and salinity at site MSM5/5-712. Data are extracted from the World Ocean atlas (Locarnini et al. 2013; Zweng et al. 2013).

species-rich diatom assemblages to environmental changes, the diatom distribution is particularly suitable for reconstructions of near-surface ecological and environmental conditions (see Koç Karpuz \& Schrader 1990; Smol \& Stoermer 2010). However, records on coccoliths (calcareous plates formed by coccolithophores, i.e., single-celled algae) and some data on radiolarians (protozoans producing skeletons usually made of silica) have also shown to give valuable palaeoenvironmental information (e.g., Hass et al. 2001). Our multi-proxy microfossil approach aims at a multi-facet view on changes in the eastern Fram Strait in the last two millennia.

\section{Material and methods}

Sediments for our study are from box core MSM5/5-7121 obtained from the western Svalbard continental margin $\left(78^{\circ} 54.94^{\prime} \mathrm{N}, 6^{\circ} 46.04^{\prime} \mathrm{E}\right.$, water depth $1490.5 \mathrm{~m}$, core length $46 \mathrm{~cm}$ ) during the RV Maria S. Merian cruise MSM5/5 in 2007. We use the core chronology developed by Spielhagen et al. (2011) and applied in other palaeoenvironmental studies of this core (e.g., Werner et al. 2011; Rueda et al. 2013; Werner et al. 2013; Cabedo-Sanz \& Belt 2016). The age model is based on five accelerator mass spectrometry radiocarbon datings of planktic foraminiferal shells of Neogloboquadrina pachyderma (sin.) 
(Ehrenberg); it reveals only minor changes in accumulation rates and time level of $133 \mathrm{BC}$ for the core base at $46 \mathrm{~cm}$ depth. Before $1500 \mathrm{CE}$ sedimentation rates varied between 18 and $20 \mathrm{~cm}^{\star} \mathrm{kyr}^{-1}$; later they increased up to $28 \mathrm{~cm}^{\star} \mathrm{kyr}^{-1}$.

Diatoms, coccoliths and radiolarians were studied in 43 samples spaced at every $1 \mathrm{~cm}$, corresponding to a temporal resolution of 37 to 54 years. Laboratory treatment and cleaning of dry samples was made according to the standard procedure for silica microfossils (Proshkina-Lavrenko et al. 1974; Zielinski et al. 1998) using hydrogen peroxide and sodium pyrophosphate without chloric acid. The residue was centrifuged in a heavy $\mathrm{KJ} / \mathrm{CdJ}$ liquid (specific gravity of 2.6) to separate biogenic silica remains. Diatom frustules were randomly settled on the cover glasses in Petri dishes. Micropalaeontological slides were prepared with Naphrax mounting media and analysed under a Carl Zeiss PrimoStar microscope at $1000 \times$ magnification. We tried to count at least 300 diatom specimens per slide; in many cases the entire slide was analysed. Diatom species identification followed descriptions and photographs by Jousé (1977), Makarova et al. (1988), Makarova (2002) and Strelnikova \& Tsoy (2008).

The introduction to this paper mentioned conventional warm intervals of the last 2000 years that were introduced by earlier palaeoclimatic studies. For the purposes of the current data presentation and interpretation, these intervals are accepted but we tend to refer to our data intervals and relate them to the conventional ones.

Figures were created using the free computer software programmes PanPlot (Sieger \& Grobe 2013) and Ocean Data View (Schlitzer 2016).

\section{Results}

In the description of palaeoceanographic changes we concentrated on (1) the total diatom content in the sediments and the accumulation rates as tests $\mathrm{g}^{-1}$ of bulk sediment and tests ${ }^{\star} \mathrm{cm}^{-2 \star} \mathrm{ky}^{-1}$, respectively, and (2) abundances of diatom taxa having a clear specific ecological affinity (Figs. 3-5). Total diatom abundances varied from 0 to $34^{\star} 10^{3}$ tests $^{\star} \mathrm{g}^{-1}$ of dry sediment much lower than those in modern sediments from the eastern Fram Strait close to our core site for which $51-290^{\star} 10^{3}$ tests $^{\star} \mathrm{g}^{-1}$ (Stabell 1987) and 3400-44000* $10^{3}$ tests $^{\star} \mathrm{g}^{-1}$ (Koç Karpuz \& Schrader 1990) were reported. One must note, however, that total diatom abundances in modern sediments across Fram Strait between latitudes of 78 to $80^{\circ} \mathrm{N}$ are distributed irregularly, ranging from 0 in the western Fram Strait to values up to $44000^{\star} 10^{3}$ tests $^{\star} \mathrm{g}^{-1}$ under the main influx of the AW in the south-eastern Fram

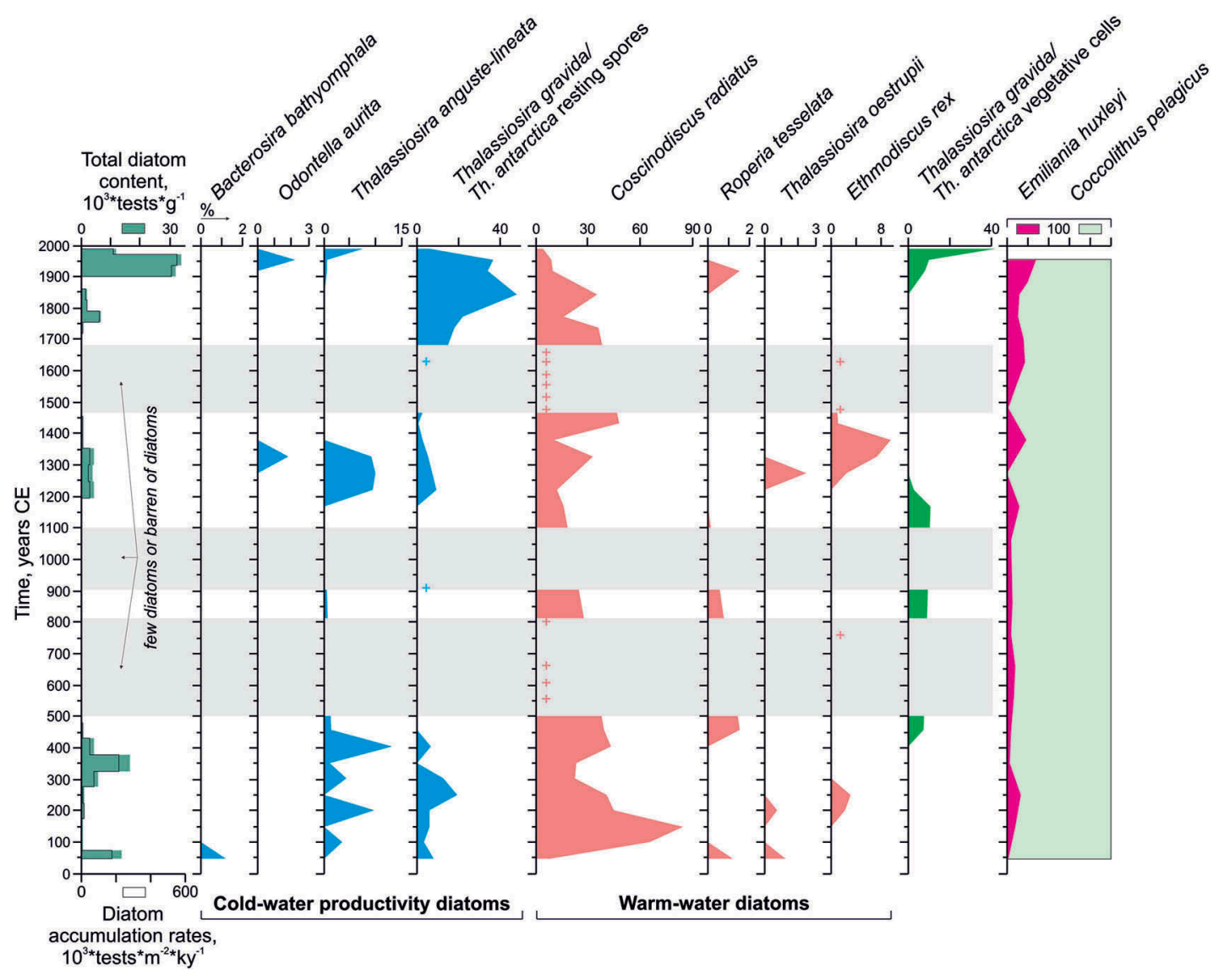

Figure 3. Down-core distribution of indicative diatom and coccoliths species. Crosses mark rare occurrences within core units with few or no diatoms. The environmental affinities of the diatoms, according to references in Table 1 and discussion in this article, are indicated at the bottom of the diagram. 


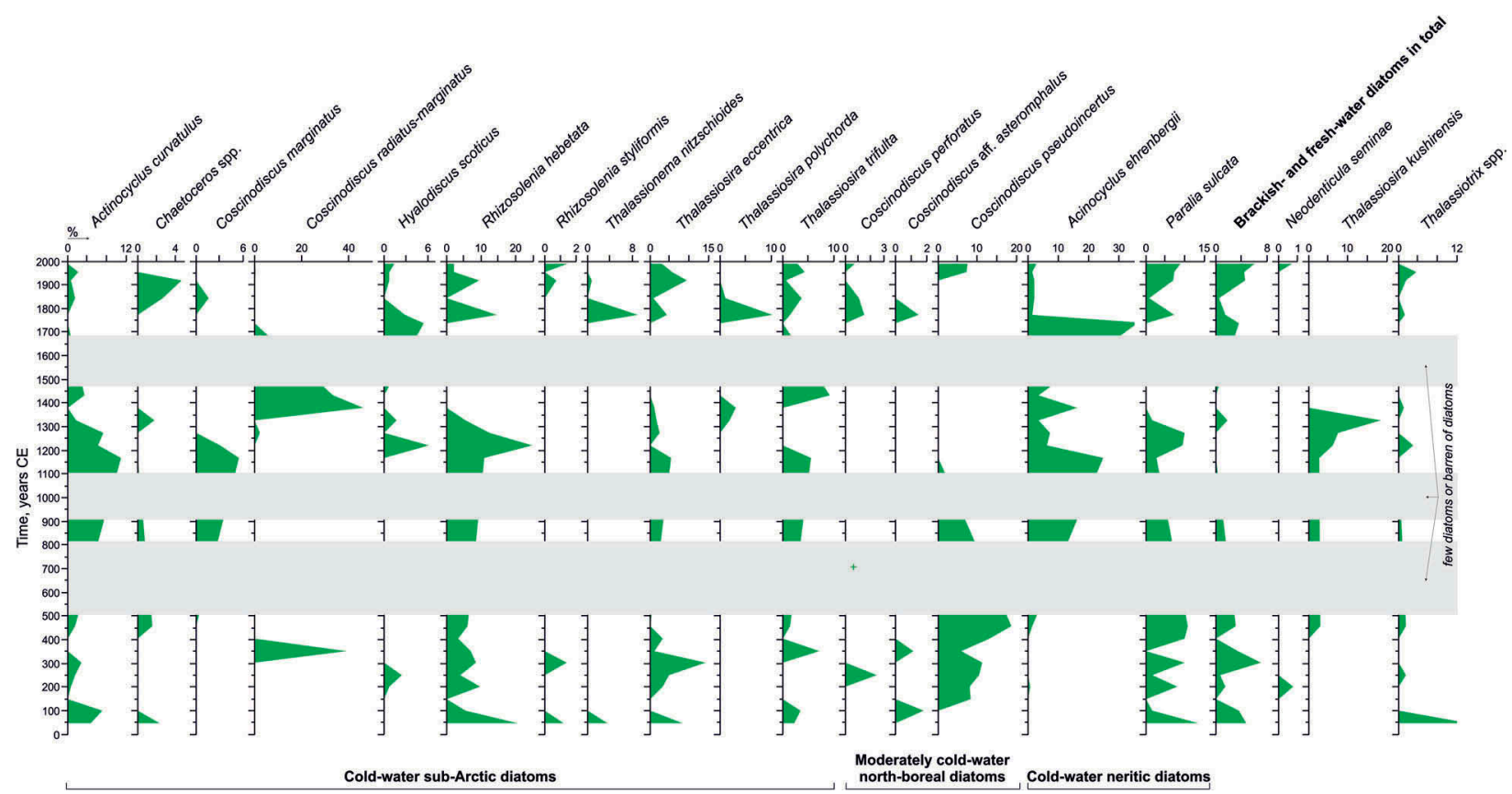

Figure 4. Down-core distribution of other (besides indicative) diatom species. The environmental affinity of diatoms, according to references in Table 1, is indicated at the bottom of the diagram.

Strait (Stabell 1987; Koç Karpuz \& Schrader 1990). Some units of our core contained only few diatom tests or were barren of diatoms: sediments from intervals of 506-810 CE (younger part of the DACP), 911-1112 CE (early part of the MCA) and 1483-1664 CE (most parts of the LIA). Highest total amounts of diatoms were found in three intervals from 46-404 CE (final part of the RWP), 1219-1380 $\mathrm{CE}$ (younger part of the MCA and just before the LIA) and with a particularly strong abundance peak after 1772 CE (final part of the LIA and the RW). Overall, abundances of major indicative species/ groups of species, especially warm-water diatoms (see description and discussion below) change in line with total abundances.

Using data on the bulk sediment accumulation rates in the core, we calculated diatom accumulation rates. These varied from $0-125$ to almost $560^{\star} 10^{3}$ tests $^{\star} \mathrm{cm}^{-2 \star} \mathrm{ky}^{-1}$. As bulk sediment accumulation rates did not change significantly throughout the core (11.51-17.37 $\mathrm{g}^{*} \mathrm{~cm}^{-2 *} \mathrm{ky}^{-1}$ ), diatom accumulation rates variations resemble those of the total diatom content. Peaks of diatom accumulation rates were found at the end of the RWP and during the $\mathrm{RW}$, with up to $219^{\star} 10^{3}$ and $560^{\star} 10^{3}$ tests $^{\star} \mathrm{cm}^{-2 \star} \mathrm{ky}^{-1}$, respectively.

We found 48 diatom taxa including 10 brackish- and freshwater species (Figs. 3, 4). A biogeographic/environmental summary and references on 31 abundant or/and stably occurred diatom taxa (except for brackish-water and freshwater ones) is presented in Table 1 . The list of marine species is composed of diatoms that occur in a wide range of cold- to moderately cold-water marine environments in the Arctic-boreal, north- and south- boreal areas, e.g., Actinocyclus curvatulus Janish, species of Coscinodiscus genus, Rhizosolenia hebetata Bailey, Thalassiosira trifulta Fryxell, Thalassionema nitzschioides (Grunow) Mereschkowsky and Thalassiotrix spp. Their relative amounts varied from 0 to $7-10 \%$, sometimes to $13-18 \%$, but abundance peaks had no clear relation to specific core units. Chaetoceros spp. resting spores, which could be an indicator of cold-water productivity, appeared $(<2 \%)$ in two samples from the RWP unit, one sample of the MCA unit and some samples (up to $4 \%)$ from the late LIA and the beginning of the RW. Significant percentages (3-18\%) of diatom species Thalassiosira aff kushirensis Takano were present in sediments of the late RWP and the late MCA. This species has, according to different reports, an alternative habitat in warmer, temperate Atlantic (Krawczyk et al. 2012) or cold Arctic (Weckström et al. 2014) water so that we hesitate to use it as a reliable palaeoenvironmental proxy. Typical sea-ice species like Fragilariopsis cylindrus (Grunow) Helmcke \& Krieger and F. oceanica (Cleve) Hasle were not found. This fact is puzzling because both species were present in sediment surface samples from Fram Strait off western Svalbard (Miettinen et al. 2015). As diatoms were rare or even absent in some core intervals, we cannot exclude dissolution of the fragile small Fragilariopsis frustules during sedimentation. Another speculative explanation could be the existence of episodes of nearly sea-ice free palaeoenvironments in the eastern Fram Strait during warmer periods of the last 2000 years.

As mentioned above, diatom species with a purely "classical" biogeographic definition (Arctic-boreal, north- and south-boreal, etc.) had no distinct association of their abundance peaks within certain units of 


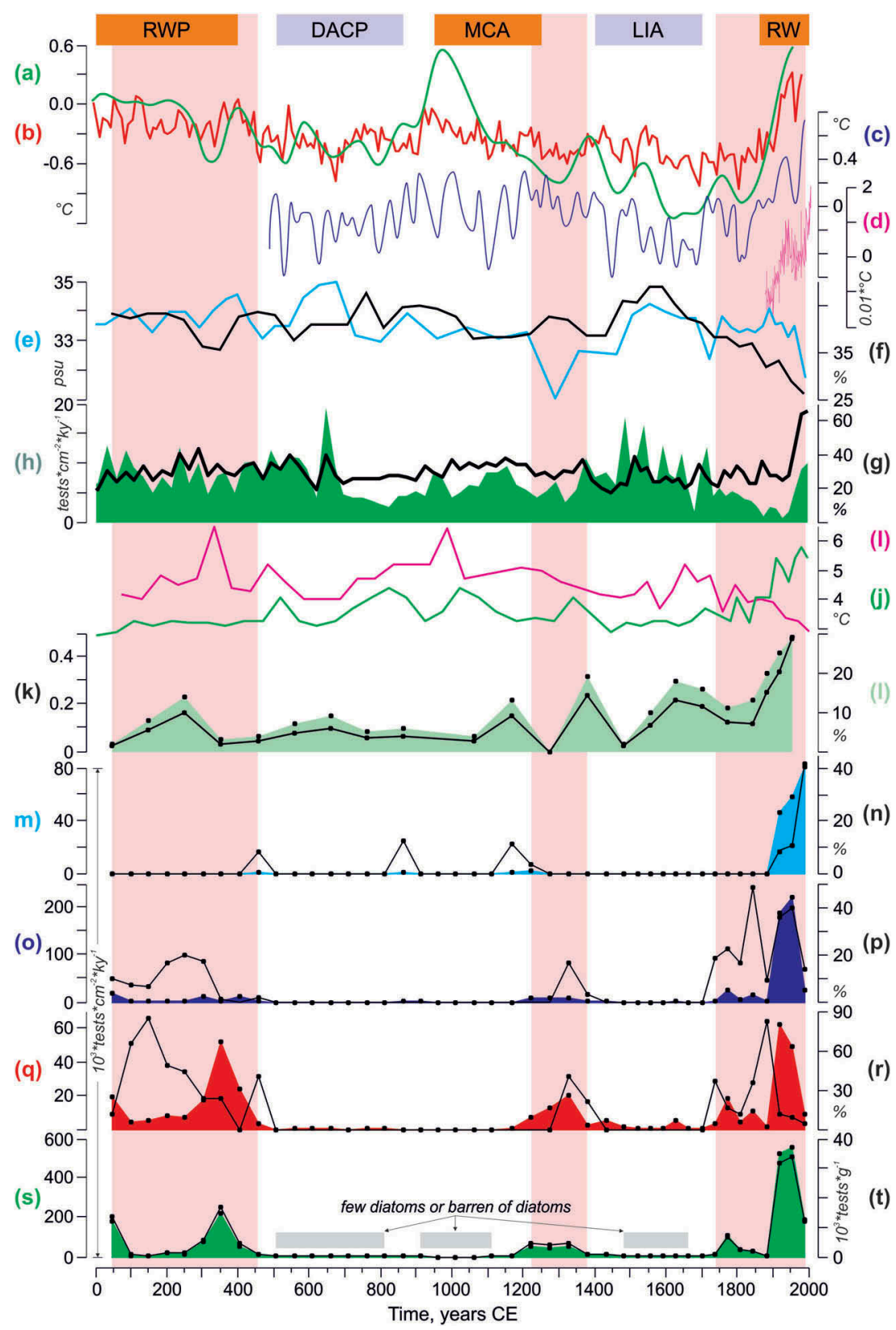

Figure 5. Palaeoenvironmental data for the eastern Fram Strait (from core MSM5/5-712-1) in comparison with other palaeoclimatic archives. Conventional palaeoclimatic intervals within the last 2000 years (Mann et al. 2009; Eldevik et al. 2014). Vertical pink bands are warm intervals based on the diatom distribution in core MSM5/5-712-1 (this study). Global/regional palaeoclimatic records: (a) green line is the Northern Hemisphere temperature (Christiansen \& Ljungqvist 2012); (b) red line is the Arctic summer temperature (Kaufman et al. 2009); (c) dark blue line is the Northern Hemisphere anomaly of summer temperature (Guillet et al. 2017); (d) purple line is the Northern Hemisphere annual Land-Ocean Temperature Index (GISTEMP Team 2017). Palaeoenvironmental reconstructions on core JM-06-WP-04-MCB (Bonnet et al. 2010): (e) blue line is summer sea-surface salinity; (f) black line is spring sea-ice concentration. Palaeoenvironmental information on core MSM5/5-712-1: (g) black line is relative abundance of the subpolar planktic foraminifera (Spielhagen et al. 2011); (h) green filling is distribution of accumulation rates of the planktic foraminifera (Spielhagen et al. 2011); (i) purple line is summer SST based on $U^{k}{ }_{37}$-index (Rueda et al. 2013); (j) green line is SIMMAX summer temperature at $50 \mathrm{~m}$ depth based on planktic foraminifera (Spielhagen et al. 2011); (k) black line is $E$. huxleyi/C. pelagicus ratio (from $\mathrm{k}$ to $\mathrm{t}$ is from this study); (I) light green filling is $E$. huxleyi distribution; $(\mathrm{m})$ blue fill and $(\mathrm{n})$ black line are Th. gravida/Th. antarctica vegetative cells accumulation rates and percentages, respectively; (o) dark blue fill and ( $p$ ) black line are cold-water productivity diatom accumulation rates and percentages, respectively; (q) red fill and ( $r$ ) black line are warm-water diatom accumulation rates and percentages, respectively; (s) green fill and (t) black line are total diatom accumulation rates and content in dry bulk sediment, respectively.

the analysed core. In our palaeoenvironmental interpretation, we focus on the distribution of two diatom groups with fairly clear environmental affinities: the four warm-water species Coscinodiscus radiatus Ehrenberg (C. radiatus), Roperia tesselata (Roper)
Grunow (R. tesselata), Thalassiosira oestrupii (Ostenfeld) Hasle (Th. oestrupii) and Ethmodiscus rex (Wallich) Hendey (E. rex); and the four coldwater productivity species (occurring also at the seaice margin) Bacterosira bathyomphala (Gran) 


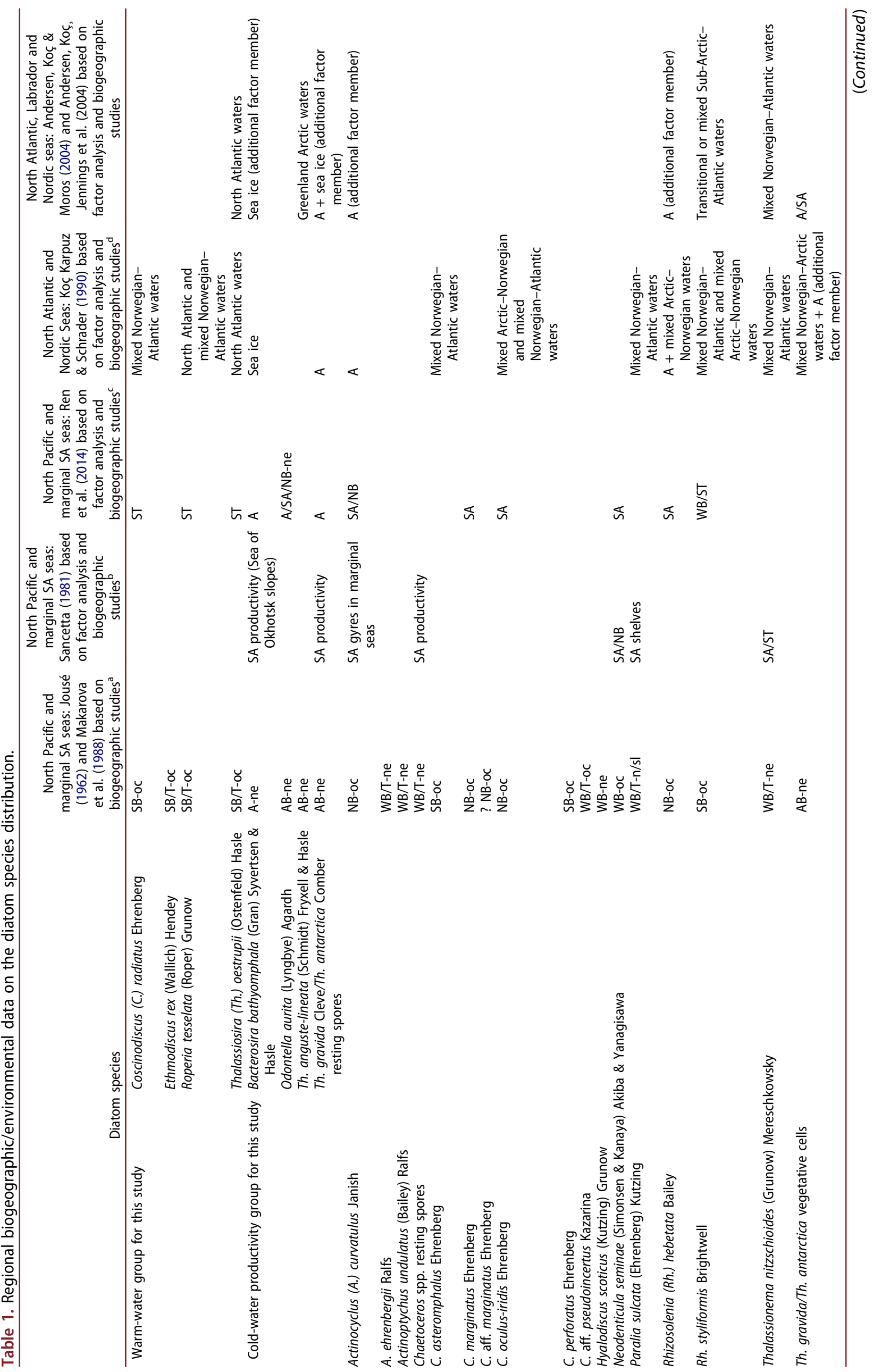


Syvertsen \& Hasle (B. bathyomphala), Odontella aurita (Lyngbye) Agardh (O. aurita), Thalassiosira anguste-lineata (Schmidt) Fryxell \& Hasle (Th. angustelineata)and Thalassiosira gravida Cleve/Thalassiosira antarctica Comber (Th. gravida/Th. antarctica) resting spores. Coscinodiscus radiatus showed by far the highest relative abundances (max. 85\%) and made up more than $25 \%$ of all diatoms in the RWP. Its other relative abundance peaks occurred at the end of the MCA (75\%) and at the onset of the RW (80\%). Peak values were found, however, only in samples with relatively low total abundances; in diatom-rich layers the relative abundance of $C$. radiatus remained $<30 \%$. Those layers held a larger variety of different species and relatively high amounts of, e.g., Th. oestrupii, E. rex and Th. anguste-lineata, as well as Th. gravida/Th. antarctica vegetative cells and resting spores. In a few cases, even "exotic" species were found. For example, two samples from the uppermost and lowermost parts of the core held sporadic tests of the diatom species Neodenticula seminae (Simonsen \& Kanaya) Akiba \& Yanagisawa (N. seminae) that is typical for the modern and Quaternary North Pacific (Ren et al. 2014).

Coccoliths are present throughout the core (Fig. 3). Only two species were found. Coccolithus pelagicus Bown (C. pelagicus) and Emiliania huxleyi (Lohmann) Hay \& Mohler (E. huxleyi) are Arctic Water and AW proxies, respectively (Samtleben et al. 1995). The E. huxleyi/C. pelagicus ratio, which can be used as a measure of the Arctic/Atlantic water influence (Andruleit \& Baumann 1998), was on average ca. 0.01 in most parts of the core, revealing the typical Arctic environments found in the research area. Only during the RW did this ratio increase to $0.25-0.48$ (Fig. 5).

\section{Discussion}

\section{Coccolith record}

The coccolith distribution in core MSM5/5-712-1 exhibits a rather monotonous palaeoenvironmental signal (Figs. 3, 5). Subtle peaks of percentages of the AW indicator E. huxleyi may point to some warming by the end of the RWP and MCA, and before the onset of the LIA. The high relative abundance of $E$. huxleyi up to $30 \%$ in the uppermost part of the core is comparable with modern values in the Fram Strait (Samtleben et al. 1995) and reflects the strong warming from the end of the LIA to present (Fig. 2). Dylmer et al. (2013) described a similar pattern of variability in the coccolith assemblages through time from a core taken $160 \mathrm{~km}$ to the south $\left(77.6^{\circ} \mathrm{N}\right)$ but reported much higher abundances of $E$. huxleyi during the MCA and RW (30-40\%). Most likely this difference can be related to the more northerly and ice-proximal position of our core. However, 
comparing our diatom and coccolith data to results of $\mathrm{U}^{\mathrm{k}}{ }_{37}$-based SST reconstructions for our core (Rueda et al. 2013) is puzzling (Fig. 5). The variability in the palaeotemperature record is not consistent with the distribution of coccolith species. This is most obvious for the RW interval: the $\mathrm{U}_{37}^{\mathrm{k}}$ record indicates a temperature decrease while the relative abundance of E. huxleyi (one of two marine producers of the alkenones raising the $\mathrm{U}_{37}^{\mathrm{k}}$ value; see Volkman et al. 1980) increases (Fig. 2). From these two coccolithbased records, only data on the increased content of the AW indicator E. huxleyi reflect a pronounced recent warming trend in the Northern Hemisphere and Arctic.

We can only speculate about the reason for the discrepancy between $\mathrm{U}^{\mathrm{k}}{ }_{37}$ values and E. huxleyi percentages. Lateral advection may play a role here, possibly in a grain size-selective way so that coccoliths and alkenones are from slightly different places of origin. Ecological issues can also be discussed, possibly related to light intensities at the sea surface, nutrients and iron availability and distribution, water chemistry (dissolved carbon dioxide, carbonate ion concentration), grazing, etc. (Tyrrell \& Merico 2004). Further modern ecological and palaeoenvironmental studies in seasonally ice-covered oceans seem necessary to understand the somewhat enigmatic coccolith records from our core. As Bendle \& RosellMelé (2004) reported, there may also exist limitations for accurate alkenone-based estimates of SST for different geographical areas within the Nordic Seas.

\section{Changes in total diatom abundances}

While total diatom abundances in our core are generally low compared to those in Holocene sediments of the Norwegian Sea (Koç Karpuz \& Schrader 1990; Koç Karpuz \& Jansen 1992), sediments from warmer intervals often hold an increased content of diatoms, especially during the time interval of ca. 300-400 CE (late RWP) and the 20th century (RW) (Figs. 3, 5). High numbers of diatoms in bottom sediments are typical for areas of elevated phytoplankton production in the modern sub-Arctic seas (Koç Karpuz \& Jansen 1992). In the Nordic Seas, a general warming at the onset of the Holocene is clearly indicated by a high diatom accumulation in bottom sediments (Koç Karpuz \& Schrader 1990; Koç Karpuz \& Jansen 1992; Berner et al. 2011). Generally, one should always consider the simultaneous decrease of terrigenous ice-rafted and particulate material during the early Holocene warming, which may add some bias to the palaeoenvironmental interpretation of total diatom concentrations in high-latitude sediments. However, this is not the case for our sediment core as bulk sediment accumulation rates did not change significantly (see Spielhagen et al. 2011).
There is another issue regarding the relation of the diatom content to warmings/coolings. Studies of Kubiszyn et al. (2014), Nöthig et al. (2015) and Soltwedel et al. (2016) document a termination of dominance of diatoms in Fram Strait phytoplankton communities in the warmest years of 1998-2012; the leading phytoplankton groups became coccolithophores dominated by E. huxleyi, then haptophyte Phaeocystis pouchetii (Hariot) Lagerheim (Ph. pouchetii) and other pico- and nanophytoplankton species. Kubiszyn et al. (2014) argued that the recent Arctic warming can induce a stronger near-surface stratification that improves the conditions for mobile flagellated phototrophs, whereas less mobile diatoms prefer to inhabit actively mixed waters. Another factor limiting diatoms in the strongly stratified waters in warming Arctic environments is a weaker transfer of nutrients from below the pycnocline, which results in a stronger development of small-sized pico- and nanophytoplankton (Moran et al. 2010). The availability of silicate can be critical for the diatom habitat as diatom dominance occurs if the silicate concentration in the water is $>2 \mu \mathrm{M} / \mathrm{l}$ (Egge \& Aksnes 1992). The largest import of silicate to the Arctic is from the North Pacific via the Bering Strait (Torres-Valdés et al. 2013). Falck et al. (2005) explained the sharp decrease of the silicate concentration at depths of $0-150 \mathrm{~m}$ in the north-western Fram Strait in 2004 compared to the previous ca. 20 years as the result of a strong reduction of the North Pacific Water contribution to the East Greenland Current; they speculated that a change in the direction of the Transpolar Drift during the recent warming could displace or even terminate a transport of North Pacific Water along the Canadian-Greenland margin. Rey (2012) also documented a decline in silicate concentrations in the Norwegian and Barents seas since 1990 due to a stronger influence of warmer, silicate-depleted AW. Although silicate-rich Pacific Water inflow seems confined to the western Fram Strait (Falck et al. 2005), findings of Pacific diatom Neodenticula seminae in surface sediments from the entire Fram Strait (Miettinen et al. 2013) suggest that imported silicate finds a way to the east, at least during periods of enhanced Pacific Water transport.

Schlüter et al. (2001) analysed the fluxes and burial of biogenic silica (BSi) in the Nordic Seas. They explained low BSi accumulations on the sea floor by the high degree of $\mathrm{Si}$ undersaturation due to low silicate concentrations in the water, also by a specific diatom physiology, dissolution kinetics, etc. As Schlüter et al. (2001) proposed, under very dynamic sea-ice conditions the BSi concentrations could be generally low in bottom sediments because the total BSi record integrates signals of both enhanced and reduced biogenic production from areas with a high spatial and temporal variability of the sea-ice extent. 
At the same time, a higher burial of BSi can occur under stable sea-ice conditions, e.g., in polynyas. Studies of the last years on the silicon sink in the Arctic revealed high concentrations of dissolved Si in porewater of the uppermost centimetres of sediments from the Arctic shelf (e.g., Sun et al. 2017). Authors refer to the active dissolution of biogenic silica and diagenetic processes in sediments.

The above factors (single or in combination) may explain the sharp decline of diatom abundances in our core during the latest part of the RW and in other time intervals, e.g., the MCA, where diatoms are scarce or absent in the sediments. Sediment cores of very high temporal resolution would be needed to prove this hypothesis. Also, further diatom studies on water samples, sediment traps and sediment cores from (sub-)Arctic seas are needed to reveal the effects of Arctic warming on diatoms.

\section{Distribution of indicative diatom groups}

The comparatively variable diatom record of core MSM5/5-712-1 allows drawing more detailed information on the surface environment than the coccolith record (Figs. 3-5). Particularly important for this study, the relatively abundant diatoms C. radiatus, $R$. tesselata and Th. oestrupii are warm-water species that today prefer a sub-tropical habitat with SSTs of 12.5 to $27^{\circ} \mathrm{C}$ (Ren et al. 2014). Koç Karpuz \& Schrader (1990) and Andersen, Koç \& Moros (2004) defined Th. oestrupii as the main species of the Atlantic Factor in the modern North Atlantic and Nordic Seas. In other micropalaeontological studies, Th. oestrupii was found in high numbers in the warmest part of the Holocene record ( 9 to 5 thousand years ago) off northern Iceland (Knudsen et al. 2004) and in the southern Norwegian Sea (Samtleben et al. 1995; Hoff et al. 2016). The species E. rex is well known from the Pleistocene and modern sediment records from high-productive areas (e.g., frontal zones) of the warm-water tropical to sub-tropical Atlantic, Indian and Pacific oceans (Villareal et al. 1999; De Deckker \& Gingele 2002; Kemp et al. 2006). Also, in the tropics E. rex can be more abundant during periods with a poorly developed sea-surface low-salinity layer when it can utilize silicates and nitrates from a wider depth range (De Deckker \& Gingele 2002). Its cells are very buoyant and may accumulate at the sea surface (Villareal et al. 1999), and we cannot exclude a long-distance transport by surface currents. This possibility makes E. rex a less reliable indicator of warm waters than the species mentioned before. However, it may serve as evidence of the advection of warmer surface water from the south. Accordingly, we grouped these four species as warm-water indicative. Overall, this group is dominant in sediments from intervals of strong AW advection as defined by high abundances of subpolar planktic foraminifera (Spielhagen et al. 2011), but peaks also occur in deposits from transitional climates, e.g., at the end of the MCA and in the earliest phase of the RW (Fig. 2). For this youngest and likely also strongest surface warming event, another indication of warmer conditions is an increased abundance of vegetative cells of Th. gravida/Th. antarctica. They are rare to absent in most parts of the core, but sharply increase in abundance in the uppermost core unit. In the Nordic Seas, Th. gravida/Th. antarctica vegetative cells dominate diatom assemblages in modern sediments under mixed Norwegian-Atlantic waters (Factor 6 in Koç Karpuz \& Schrader 1990) with summer SSTs of $9-12^{\circ} \mathrm{C}$, but are also a prominent component of the Arctic water assemblages (Factor 2 in Koç Karpuz \& Schrader 1990) at a rather wide range of summer SSTs from 0.1 to $11.3^{\circ} \mathrm{C}$. Therefore, we cannot classify this species as a purely temperate one indicating only AW advection. According to the data of Andersen et al. (Andersen, Koç, Jennings et al. 2004; Andersen, Koç \& Moros 2004), this species can have a cooler water habitat (compared to mixed Norwegian-Atlantic waters) as it belongs to the East and West Greenland Current assemblages (Factor 7) in the area of Arctic/subArctic Waters. Kazarina \& Yushina (1999) found its highest abundances (up to $30 \%$ ) in modern sediments of the sub-Arctic Pacific at SST of $7^{\circ} \mathrm{C}$. In sediment samples of our core with highest abundances of $T h$. gravida/Th. antarctica vegetative cells we found radiolarian assemblages that are typical for the modern northern Norwegian Sea, with dominating species Actinomma leptodermum leptodermum (Joergensen), Larcospyra minor (Joergensen), Lithocampe platycephala (Ehrenberg), Phorticium clevei (Joergensen), Pseudodyctiophimus gracilipes (Bailey) and Amphimelissa setosa (Cleve) (Kruglikova, unpubl. data). These species represent modern radiolarian microfauna in the areas of the Nordic Seas where an interaction of the warmer Atlantic and cold Arctic/Polar waters occur. They have highest scores in factors (assemblages) distributed under the water masses with SST ranging from $2-3$ to $8-10^{\circ} \mathrm{C}$ (Bjørklund et al. 1998), which is close to SST affinity of Th. gravida/Th. antarctica vegetative cells and to modern SST of the West Spitsbergen Current in the study area (Norwegian Polar Institute 2017).

The diatom Th. gravida/Th. antarctica resting spores generally indicate Arctic waters with SST between the freezing point and $8^{\circ} \mathrm{C}$ (Koç Karpuz \& Schrader 1990; Andersen, Koç \& Moros 2004). Factor analysis of the diatom distribution in the Nordic Seas reveals a relation of the diatom species Th. angustelineata to cold-water environments in Arctic waters and (together with the sea-ice species Nitzschia [Fragilariopsis] spp.) in Polar waters of the East 
Greenland Current (Hass et al. 2001; Andersen, Koç \& Moros 2004). Diatom species B. bathyomphala and $O$. aurita were found in ice-core samples of first-year ice in the Chukchi Sea, the former also in the sub-ice water (von Quillfeldt et al. 2003). Koç Karpuz \& Schrader (1990) and Andersen, Koç \& Moros 2004) described B. bathyomphala as an additional but not the major component of diatom assemblages in the marginal sea-ice areas of the Nordic Seas. Sancetta (1981, 1982) classified Th. gravida/Th. antarctica resting spores, B. bathyomphala and $O$. aurita in the group of the sub-Arctic cold-water productivity species. We therefore regard them, together with $T h$. anguste-lineata, as being indicative of cold-water productivity and, probably, the proximity of the marginal ice zone-an area of nutrient release and hydrological conditions (Ekman upwelling at the sea-ice edge, vertical mixing induced by winter cooling and brine production, etc.) that are favourable for bioproductivity and high fluxes of biogenic silica (Ramseier et al. 1999). The environments characterized by the cold-water productivity group may feature melting ice, open water close to sea ice and cold ice-free waters in the area of seasonal sea-ice retreat. During warm events, the cold-water diatoms Th. gravida/Th. antarctica resting spores and Th. anguste-lineata were not dominant, indicating seasonal (not nearly perennial) Arctic Water environments at the sea surface. This finding supports data on moderately heavy spring sea-ice conditions (concentration of 35 to 45\%) in the eastern Fram Strait during the last 2000 years (Cabedo-Sanz \& Belt 2016).

\section{Warming intervals based on diatoms versus other microfossils}

Using the distribution of total diatom abundances and the palaeoenvironmental evidence from the groups as defined above, our diatom record reveals three distinct episodes of elevated sea-surface temperatures during the last 2000 years: 46 to $455 \mathrm{CE}$ in the later part of the RWP; 1166 to $1434 \mathrm{CE}$ in the final part of the MCA and the transition to the LIA; and $1736 \mathrm{CE}$ to present from the late LIA and in the RW (Fig. 5). Data on diatoms have good visual correlation with the reconstructed Northern Hemisphere and Arctic temperature anomalies during the last two millenia (Kaufman et al. 2009; Christiansen \& Ljungqvist 2012; Guillet et al. 2017) and observed recent temperature trends (GISTEMP Team 2017). Some caution has to be applied, however, since several sections of our core are barren in diatoms and do not allow a comparison of diatom-derived climate reconstructions for the eastern Fram Strait to supraregional records.

Estimating temperature variability from the distribution of indicative warm-water diatom species, the time interval of 46 to $455 \mathrm{CE}$ (the final phase of the RWP) appears the most pronounced, long warm sea surface interval in our record: percentages of $C$. radiatus are persistently high from $25-30$ to $70-90 \%$. Further, the sub-tropical indicators $R$. tesselata, Th. oestrupii and E. rex also appear in some samples from this time interval. The next warm interval is found in the diatom record from 1166 to 1434 CE (the final part of the MCA and the transition to the LIA), with high $C$. radiatus abundances (including two peaks up to 30 and 50\%), the appearance of Th. oestrupii, and the stable increase of the E. rex content up to $8-9 \%$. We are not able to discuss the palaeoenvironments during the main part of the conventional MCA as diatoms are almost absent in the sediments. As discussed above, local conditions at the seafloor may have been unfavourable for diatom preservation. The warming after $1736 \mathrm{CE}$ is revealed by the sharp rise of total diatom abundances, two peaks of $C$. radiatus percentages, one level of $R$. tesselata occurrence and a sharp increase of percentages of $T h$. gravida/Th. antarctica vegetative cells. Our data on diatoms support evidence for a rapid warming in Europe 1715-1750 CE, after the end of the Maunder Minimum (Tung \& Zhou 2013) as the first step of the RW.

When comparing these three warm intervals in general, the late RWP (46 to $455 \mathrm{CE}$ ) appears as the most prominent and stable one, as seen in the diatom species distribution and total diatom content. However, other warmings of the late Holocene were also very prominent. Studies of the modern radiolarian plankton on the northern Svalbard margin suggested the occurrence of short-term penetration events of tropical/sub-tropical waters deep into the Nordic Seas and Arctic in the last decades (Bjørklund et al. 2012). Physical oceanography data have clearly revealed such events (Karcher et al. 2003; Polyakov et al. 2010). Findings of "exotic" species in sedimentary records from the Laptev Sea also reveal that the occurrence of warm-water (even tropical) microplankton was not unusual in the Arctic in the middle to late Holocene (Bauch 1999; Matul et al. 2007).

Comparing the palaeoenvironmental interpretations based on various micropalaeontological data derived from the same sediment samples in our core from the eastern Fram Strait exhibits different palaeoceanographic signals from the various microfossil groups (Figs. 5, 6). Generally, they can be classified according to their habitat: (1) subsurfacedwelling planktic foraminifera; and (2) surfacedwelling diatoms, coccoliths and dinocysts. Differences can be seen even among the surface dwellers. In the following paragraph we will discuss some of the problems and implications arising from the comparison of multiproxy data sets obtained from our core (Figs. 5, 6). 


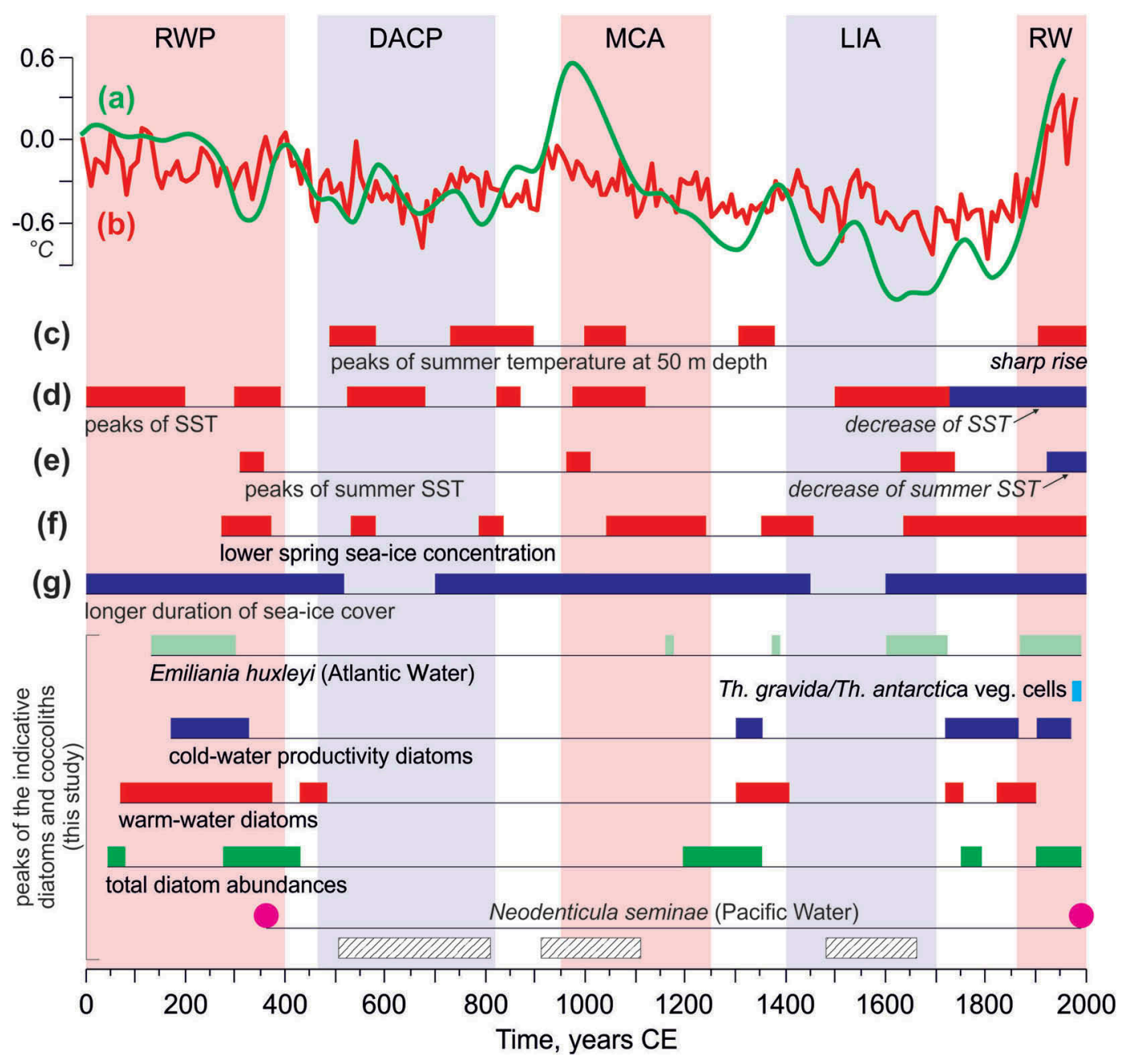

Figure 6. Palaeoclimatic events in the eastern Fram Strait. (a) Northern Hemisphere air temperature (green line; Christiansen \& Ljungqvist 2012), (b) Arctic summer air temperature (red line; Kaufman et al. 2009), (c) AW temperature at $50 \mathrm{~m}$ based on planktic foraminifera (Spielhagen et al. 2011), (d) sea-surface temperature based on dinocysts (Bonnet et al. 2010), (e) seasurface temperature based on $\mathrm{U}_{37}^{\mathrm{k}}$ (Rueda et al. 2013), (f) sea-ice coverage based on $\mathrm{IP}_{25}$ (Cabedo-Sanz \& Belt 2016), (g) sea-ice coverage based on dinocysts (Bonnet et al. 2010). Stippled rectangles mark intervals of few or no diatoms in core MSM5/5-7121. Conventional palaeoclimatic intervals (pink and light blue vertical bands) within the last 2000 years are as shown in Fig. 3.

Records of ice-rafted detritus in our core showed a distinct progressive trend of neoglacial cooling in the eastern Fram Strait during the last 2000 years, except for the RW (Werner et al. 2011). However, micropalaeontological proxies document a rather variable palaeoceanographic situation in the area, in particular when results from different microfossil groups are compared. Even data from the same group may need caution when they are used for reconstructions of ocean parameters, as shown for planktic foraminifera in our core (Spielhagen et al. 2011; Werner et al. 2011). Abundances of subpolar foraminifera and stable oxygen and carbon isotope data revealed events of slight increases of subsurface AW advection during the RWP and early DACP. Reconstructed summer subsurface temperatures, however, remained stable and low during the RWP and only increased episodically during the MCA (by $1-1.5^{\circ} \mathrm{C}$ ) and later strongly during the RW (by $3^{\circ} \mathrm{C}$ ). Maximum total abundances were found in deposits from colder periods (DACP, LIA) and rather reflect the proximity to the sea-ice margin than strong AW advection. Based on studies of biomarkers (IP 25 , HBI III and brassicasterol) in our core, Cabedo-Sanz \& Belt (2016) proposed, in contrast to the planktic foraminiferal data, only slightly changing spring sea-ice concentrations during the RWP, DACP, MCA and the beginning of the LIA, but also a rapid sea-ice margin retreat during the RW (also suggested by Köseoğlu et al. 2018). The $\mathrm{U}^{\mathrm{k}}{ }_{37}$ record (Rueda et al. 2013) from our core detected three time intervals of elevated SST (by $1-1.5^{\circ} \mathrm{C}$ ), during the late RWP, the MCA and the middle LIA at ca. $1650 \mathrm{CE}$. Following the last peak, $\mathrm{U}^{\mathrm{k}}{ }_{37}$-based SSTs show a negative trend $\left(2^{\circ} \mathrm{C}\right.$ change) towards modern, reaching a temperature of only $3^{\circ} \mathrm{C}$ as reconstructed from the sediment surface. Such reconstructed rather low temperature may reveal methodological problems since average annual SST near the core site were $>4^{\circ} \mathrm{C}$ in the last two decades (Beszczynska-Möller et al. 2012) and summer temperatures were even higher. 
In general, planktic foraminifera (total accumulation rates, relative abundances of the subpolar species, and reconstructed SIMMAX water palaeotemperature) together with coccoliths (E. huxleyi abundances) and diatoms (micropalaeontological indices, and IP25 biomarker data on the spring sea-ice concentration) revealed a pronounced warming in the last 150 years (Figs. 5, 6). For the same time, dinocysts (Bonnet et al. 2010 [a study of core JM-06-WP-04-MCB from the same location]) and the $\mathrm{U}^{\mathrm{k}}{ }_{37}$ record (Rueda et al. 2013) showed a SST decrease and indicate a longer duration of the sea-ice cover. Cabedo-Sanz \& Belt (2016) compared biomarker and dinocysts records (Bonnet et al. 2010) on the sea-ice extent in the eastern Fram Strait and found no clear agreement between them; there were some common trends in the interval 50-1400 CE but generally opposing trends after ca. $1600 \mathrm{CE}$. Moreover, dinocysts reconstructions of Bonnet et al. (2010) suggested nearly ice-free conditions between ca. 600-700 CE whereas biomarker reconstructions of Cabedo-Sanz \& Belt (2016) revealed relatively high spring sea-ice concentrations of ca. $40 \%$. As Cabedo-Sanz \& Belt (2016) proposed, such differences might be associated with a seasonal occurrence of different microfossil proxies under the influence of palaeohydrological changes.

The differences seen in data from different microfossil groups may be caused by changes in the water mass structure at the core site. Recent oceanographic data from the (sub-)Arctic may offer some clues on the mechanisms involved. As revealed by oceanographic data from the last decades (Karcher et al. 2003; Polyakov et al. 2010) the subsurface AW inflow to the north increased in volume and temperature during multi-year periods interrupted by times of colder and less vigorous inflow. In the warmer periods the inflow was compensated by a south-westward expansion of the relatively thin and fresh surface layer with water that partly originated from the Arctic Ocean, thereby increasing the stratification at our core site. Here, planktic foraminifera dwell in the subsurface AW with relatively stable hydrological parameters. Surface dwellers, however, can be assumed to reflect a wider range in the seasonal succession of environments, from colder winter to warmer summer conditions in the uppermost mixed water layer. Dale et al. (1999) analysed a three-year (1990-92) time series of the phytoplankton composition at Ocean Weather Station Mike in the Norwegian Sea at $66^{\circ} \mathrm{N}$. They found a seasonal pattern in the phytoplankton development from low biomass values in winter to a spring/summer (MayJune/July) maximum phytoplankton bloom, followed by a smaller, short second bloom in the early autumn. For our palaeoenvironmental interpretation of the microfossil data it is useful to note that the different stages of maximum phytoplankton biomass development at Ocean Weather Station Mike are marked by blooming peaks of different groups of microorganisms.
Records from this weather station revealed prevailing amounts of coccolithophores (mostly E. huxleyi) and small nanoplankton species in the winter and prebloom, followed by an after-bloom and autumn phytoplankton communities. The spring/summer bloom was dominated by diatoms, and coccolithophores production was also high. Dinoflagellates were sometimes an abundant component during the summer but generally had a scattered distribution without a distinct "dinoflagellate phase" of blooming. Dale et al. (1999) suggested that the seasonal changes in hydrographic conditions (salinity, temperature, silicate/nitrate concentration) and grazing could control such variations of the local phytoplankton. We are aware that the observations of Dale et al. (1999) were made for an area that is rather far south of our core site. However, they may still be applied to the discussion of environments in the eastern Fram Strait during pronounced Holocene warmings. Phytoplankton studies of the last years around Svalbard also exhibited time differentiation in blooming of different phototrophic groups. Piquet et al. (2014), in studies of phytoplankton blooms in the Kongsfjorden-Krossfjorden system of western Svalbard $\left(79^{\circ} \mathrm{N}\right)$ in $2007-08$, documented the typical spring bloom to consist of diatoms and haptophyte $P h$. pouchetii, and post-bloom communities dominated by dinoflagellates, nano- and picophototrophs. Importantly, the spring bloom changed to a dominance of $P h$. pouchetii communities when several incursions of warmer AW into Kongsfjorden and Krossfjorden occurred during the winter. Significant interannual differences of the prevailing groups of planktic protists were also found offshore in the Fram Strait during the Hausgarten observations in 1998-2011 (Nöthig et al. 2015) as a possible result of the increased shallow water variability (changes of temperature, sea-ice extent, stratification). Another environmental study of the phytoplankton bloom north of Svalbard in 2015 (Assmy et al. 2017) exhibited a time-transgressive dominance of diatoms, $\mathrm{Ph}$. pouchetii and other phytoplankton groups during the spring to early summer time. When these recent observations of the biotic response to oceanographic variability on multiyear timescales are used as a template for changes in the last two millennia, it becomes clear that a simple explanation of complicated basic micropalaeontological data (as in our study) is probably not straightforward. Integrated (that is, climatically averaged) fossil signals as from somewhat bioturbated marine sediments very likely always combine (palaeo) ecological information on different phases in the living habitat of the different marine microorganisms. Presumably this also accounts for the findings in our study and underlines the need for more detailed ecological phytoplankton studies and their careful consideration when it comes to interpreting multi-fossil palaeoenvironmental records. 


\section{Findings of diatom species Neodenticula seminae}

Of particular interest is the finding of rare specimens of the diatom species $N$. seminae at the levels of $173 \mathrm{CE}$ and 1989 CE in core MSM5/5-712-1 (Figs. 4, 6). Today this species is endemic and dominant in diatom assemblages of the high-productive boreal pelagic North Pacific (Jousé 1962). Previously, N. seminae was found in early-to-middle Pleistocene sediments of the North Atlantic (Baldauf 1986). To our knowledge, in the 20th century it was never described from late Quaternary Nordic Seas and Arctic records. However, more recent studies of sediments and plankton samples reported new findings of $N$. seminae. Reid et al. (2007) presented data on high numbers of $N$. seminae in the May 1999 plankton from the Labrador Sea. Starr et al. (2002) found the species in the spring 2001 plankton on the Canadian shelf in the Gulf of St. Lawrence. After 2001, N. seminae was here a regular and dominant species in the diatom phytoplankton communities. Phylogenetic analysis of specimens from this material showed the sister clades of $N$. seminae strains from the Gulf of St. Lawrence and North Pacific (Poulin et al. 2010). The occurrence of $N$. seminae in modern sediment samples (sediment surface samples), taken in 2006 to 2008 from the Fram Strait, the Greenland Sea, the East Greenland margin, and the West Spitsbergen slope, was documented by Miettinen et al. (2013). All these authors considered the regional Arctic warming since the late 1990s and associated pulses of North Pacific Water occurrence in the North Atlantic domain via the Canadian Arctic Archipelago and the Fram Strait as the most likely reason for the N. seminae expansion. Such events of interactions between the North Pacific and North Atlantic are well known for Pleistocene warm interglacial intervals, e.g., from radiolarian data (Matul \& Abelmann 2005; Bjørklund et al. 2015). Our findings of $N$. seminae specimens in sediments from the late RWP in the eastern Fram Strait reveal that in the Holocene such events were not exclusively confined to the recent warming under the "Arctic Amplification", but also occurred earlier. More detailed investigations of high-resolution records may help to investigate the significance of $N$. seminae findings for defining periods of enhanced Pacific-Atlantic water exchange across the Arctic.

\section{Conclusions}

Our collection and comparison of microfossil parameters (total microfossil abundances, concentrations of indicative species and species groups) in sediments from the last 2000 years in the eastern Fram Strait reveals pronounced variability. Overall, the palaeoenvironmental information from the diverse micropalaeontological data suggests the late RWP and the RW as the warmest intervals of the last two millennia. Nevertheless, comparing data from different microfossil groups exhibits complicated palaeoceanographic signals. Evidence for peak warmings as obtained from the different microfossils is not always in-phase. Variations in the distribution of diatoms, coccoliths and dinocysts as surface water indicators are more variable than those in planktic foraminifera that are considered as subsurface water indicators. The RW is notable for significant peaks in most microfossil indicators of warming. However, reconstructions on dinocysts and coccoliths revealed a decline of sea-surface temperatures during the RW. At the moment, we are not able to provide a satisfactory explanation of discrepancies between palaeoenvironmental signals from the different microfossils. A possible major factor may have been general changes of the surface/subsurface water structure during the Arctic warming that could have induced changes in the phototrophic communities due to variations in cold/ warm water transport, stratification, availability of nutrients, seasonal succession of the bioproductivity, vital effects, or other things.

\section{Acknowledgements}

We are grateful to the two anonymous reviewers for their valuable and constructive comments and suggestions that helped to improve the manuscript significantly. The investigated sediment core was retrieved during an expedition of RV Maria S. Merian.

\section{Disclosure statement}

No potential conflict of interest was reported by the authors.

\section{Funding}

This work was supported primarily by the Russian Science Foundation and Department of Science and Technology of the Ministry of Science and Technology of India under grant no. 16-47-02009. The funds for the same were extended by the National Centre for Polar and Ocean Research, Goa, Ministry of Earth Sciences; RM would like to thank the director of that institution for extending support to this project. Micropalaeontological work was supported by Shirshov Institute of Oceanology project no. 0149-2018-0016, granted by the Russian Federal Agency of Scientific Organizations. The expedition of RV Maria S. Merian during which the investigated sediment core was retrieved was funded by the Deutsche Forschungsgemeinschaft. This is National Centre for Polar and Ocean Research contribution no. 62/2018.

\section{ORCID}

Alexander Matul (D) http://orcid.org/0000-0002-4321-5891 Svetlana Kruglikova (D) http://orcid.org/0000-0002-65281056

Rahul Mohan (1) http://orcid.org/0000-0001-8758-2215

\section{References}

Andersen C., Koç N., Jennings A. \& Andrews J.T. 2004. Nonuniform response of the major surface currents in 
the Nordic Seas to insolation forcing: implications for the Holocene climate variability. Paleoceanography 19, PA2003, doi: 10.1029/2002PA000873.

Andersen C., Koç N. \& Moros M. 2004. A highly unstable Holocene climate in the subpolar North Atlantic: evidence from diatoms. Quaternary Science Reviews 23, 2155-2166.

Andruleit H.A. \& Baumann K.-H. 1998. History of the Last Deglaciation and Holocene in the Nordic Seas as revealed by coccolithophore assemblages. Marine Micropaleontology 35, 179-201.

Assmy P., Fernández-Méndez M., Duarte P., Meyer A., Randelhoff A., Mundy C.J., Olsen L.M., Kauko H.M., Bailey A., Chierici M., Cohen L., Doulgeris A.P., Ehn J. K., Fransson A., Gerland S., Hop H., Hudson S.R., Hughes N., Itkin P., Johnsen G., King J.A., Koch B.P., Koenig Z., Kwasniewski S., Laney S.R., Nicolaus M., Pavlov A.K., Polashenski C.M., Provost C., Rösel A., Sandbu M., Spreen G., Smedsrud L.H., Sundfjord A., Taskjelle T., Tatarek A., Wiktor J., Wagner P.M., Wold A., Steen H. \& Granskog M.A. 2017. Leads in Arctic pack ice enable early phytoplankton blooms below snow-covered sea ice. Scientific Reports 7, article no. 40850, doi: 10.1038/srep40850.

Baldauf J.G. 1986. Diatom biostratigraphic and palaeoceanographic interpretations for the middle to high latitude North Atlantic Ocean. In C.P. Summerhayes \& N.J. Shackleton (eds.): North Atlantic palaeoceanography. Geological Society Special Publication 21. Pp. 243-252. London: Geological Society.

Bauch H.A. 1999. Planktic foraminifera in Holocene sediments from the Laptev Sea and the central Arctic Ocean: species distribution and paleobiogeographical implication. In H. Kassens et al. (ed.): Land-ocean systems in the Siberian Arctic: dynamics and history. Pp. 601-613. Berlin: Springer.

Bendle J. \& Rosell-Melé A. 2004. Distributions of $\mathrm{U}^{\mathrm{K}}{ }_{37}$ and $\mathrm{U}^{\mathrm{K}}{ }_{37}$ in the surface waters and sediments of the Nordic Seas: implications for paleoceanography. Geochemistry Geophysics Geosystems 5, Q11013, doi: 10.1029/ 2004GC000741.

Berner K.S., Koç N., Godtliebsen F. \& Divine D. 2011. Holocene climate variability of the Norwegian Atlantic Current during high and low solar insolation forcing. Paleoceanography 26, PA2220, doi: 10.1029/ 2010 PA002002.

Beszczynska-Möller A., Fahrbach E., Schauer U. \& Hansen E. 2012. Variability in Atlantic Water temperature and transport at the entrance to the Arctic Ocean, 1997-2010. ICES Journal of Marine Science 69, 852-863.

Bjørklund K.R., Cortese G., Swanberg N.R. \& Schrader H.J. 1998. Radiolarian faunal provinces in surface sediments of the Greenland, Iceland and Norwegian (GIN) seas. Marine Micropaleontology 35, 105-140.

Bjørklund K.R., Hatakeda K., Kruglikova S.B. \& Matul A.G. 2015. Amphimelissa setosa (Cleve) (Polycystina, Nassellaria) - a stratigraphic and paleoecological marker of migrating polar environments in the Northern Hemisphere during the Quaternary. Stratigraphy 12, 23-37.

Bjørklund K.R., Kruglikova S.B. \& Anderson O.R. 2012. Modern incursions of tropical Radiolaria into the Arctic Ocean. Journal of Micropalaeontology 31, 139-158.

Bonnet S., de Vernal A., Hillaire-Marcel C., Radi T. \& Husum K. 2010. Variability of sea-surface temperature and sea-ice cover in the Fram Strait over the last two millennia. Marine Micropaleontology 74, 59-74.
Briner J.P., McKay N.P., Axford Y., Bennike O., Bradley R. S., de Vernal A., Fisher D., Francus P., Fréchette B., Gajewski K.J., Jennings A., Kaufman D.S., Miller G., Rouston C. \& Wagner B. 2016. Holocene climate change in Arctic Canada and Greenland. Quaternary Science Reviews 147, 340-364.

Cabedo-Sanz P. \& Belt S.T. 2016. Seasonal sea ice variability in eastern Fram Strait over the last 2000 years. Arktos 2, article no. 22, doi: 10.1007/s41063-016-0023-2.

Cherkasheva A., Bracher A., Melsheimer C., Köberle C., Gerdes R., Nöthig E.-M., Bauerfeind E. \& Boetius A. 2014. Influence of the physical environment on polar phytoplankton blooms: a case study in the Fram Strait. Journal of Marine Systems 132, 196-207.

Christiansen B. \& Ljungqvist F.C. 2012. The extra-tropical Northern Hemisphere temperature in the last two millennia: reconstructions of low-frequency variability. Climate of the Past 8, 765-786.

Dale T., Rey F. \& Heimdal B.R. 1999. Seasonal development of phytoplankton at a high latitude oceanic site. Sarsia 84, 419-435.

De Deckker P. \& Gingele F.X. 2002. On the occurrence of the giant diatom Ethmodiscus rex in an 80-ka record from a deep-sea core southeast of Sumatra, Indonesia: implications for tropical palaeoceanography. Marine Geology 183, 31-43.

Dylmer C.V., Giraudeau J., Eynaud F., Husum K. \& de Vernal A. 2013. Northward advection of Atlantic Water in the eastern Nordic Seas over the last 3000 yr. Climate of the Past 9, 1505-1518.

Egge J.K. \& Aksnes D.L. 1992. Silicate as regulating nutrient in phytoplankton competition. Marine Ecology Progress Series 83, 281-289.

Eldevik T., Risebrobakken B., Bjune A.E., Andersson C., Birks H.J.B., Dokken T.M., Drange H., Glessmer M.S., Li C., Nilsen J.E.Ø., Otterå O.H., Richter K. \& Skagseth Ø. 2014. A brief history of climate-the northern seas from the Last Glacial Maximum to global warming. Quaternary Science Reviews 106, 225-246.

Falck E., Kattner G. \& Budéus G. 2005. Disappearance of Pacific Water in the northwestern Fram Strait. Geophysical Research Letters 32, L14619, doi: 10.1029/ 2005GL023400.

GISTEMP Team 2017. GISS Surface Temperature Analysis (GISTEMP). NASA Goddard Institute for Space Studies. Accessed on the internet at https://data.giss.nasa.gov/ gistemp on 23 April 2018.

Guillet S., Corona C., Stoffel M., Khodri M., Lavigne F., Ortega P., Eckert N., Sielenou P.D., Daux V., Churakova (Sidorova) O.V., Davi N., Edouard J.-L., Zhang Y., Luckman B.H., Myglan V.S., Guiot J., Beniston M., Masson-Delmotte V. \& Oppenheimer C. 2017. Climate response to the Samalas volcanic eruption in 1257 revealed by proxy records. Nature Geoscience 10, 123-128.

Hass C., Andruleit H., Baumann A., Baumann K.H., Kohly A., Jensen S., Matthießen J., Samtleben C., Schäfer P., Schröder-Ritzrau A. \& Thiede J. 2001. The potential of synoptic plankton analyses for paleoclimatic investigations: five plankton groups from the Holocene Nordic Seas. In P. Schäfer et al. (eds.): The northern North Atlantic: a changing environment. Pp. 291-318. Berlin: Springer.

Hoff U., Rasmussen T.L., Stein R., Ezat M.M. \& Fahl K. 2016. Sea ice and millennial-scale climate variability in the Nordic Seas $90 \mathrm{kyr}$ ago to present. Nature Communications 7, article no. 12247, doi: 10.1038/ ncomms 12247 . 
Holland D.M., Mysak L.A. \& Oberhuber J.M. 1996. An investigation of the general circulation of the Arctic Ocean using an isopycnal model. Tellus Series A 48, 138-157.

Jousé A.P. 1962. Stratigraphic and paleogeographic studies in the northwestern part of the Pacific Ocean. Moscow: Academy of Sciences of USSR.

Jousé A.P. (ed.) 1977. Atlas of microorganisms in bottom sediments of the oceans (diatoms, radiolarians, silicoflagellates, coccoliths). Moscow: Nauka Press.

Karcher M., Gerdes R., Kauker F. \& Köberle C. 2003. Arctic warming: evolution and spreading of the 1990s warm event in the Nordic seas and the Arctic Ocean. Journal of Geophysical Research-Oceans 108, 3034, doi: 10.1029/2001JC001265.

Kaufman D.S., Schneider D.P., McKay N.P., Ammann C. M., Bradley R.S., Briffa K.R., Miller G.H., Otto-Bliesner B.L., Overpeck J.T., Vinther B.M. \& Arctic Lakes $2 \mathrm{k}$ Project Members. 2009. Recent warming reverses longterm Arctic cooling. Science 325, 1236-1239.

Kazarina G.K. \& Yushina I.G. 1999. Diatoms in recent and Holocene sediments of the North Pacific and Bering Sea. Berichte zur Polarforshung 306, 120-133.

Kemp A.E.S., Pearce R.B., Grigorov I., Rance J., Lange C.B., Quilty P. \& Salter I. 2006. Production of giant marine diatoms and their export at oceanic frontal zones: implications for $\mathrm{Si}$ and $\mathrm{C}$ flux from stratified oceans. Global Biogeochemical Cycles 20, GB4S04, doi: 10.1029/ 2006 GB002698.

Knudsen K.L., Jiang H., Jansen E., Eiríksson J., Heinemeier J. \& Seidenkrantz M.-S. 2004. Environmental changes off North Iceland during the deglaciation and the Holocene: foraminifera, diatoms and stable isotopes. Marine Micropaleontology 50, 273-305.

Koç Karpuz N. \& Jansen E. 1992. A high-resolution diatom record of the last deglaciation from the SE Norwegian Sea: documentation of rapid climatic changes. Paleoceanography 7, 499-520.

Koç Karpuz N. \& Schrader H. 1990. Surface sediment diatom distribution and Holocene paleotemperature variations in the Greenland, Iceland and Norwegian Sea. Paleoceanography 5, 557-580.

Köseoğlu D., Belt S.T., Smik L., Yao H., Panieri G. \& Knies J. 2018. Complementary biomarker-based methods for characterising Arctic sea ice conditions: a case study comparison between multivariate analysis and the PIP25 index. Geochimica et Cosmochimica Acta 222, 406-420.

Krawczyk D., Witkowski A., Wroniecki M., Waniek J.,

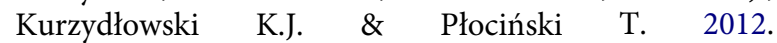
Reinterpretation of two diatom species from the West Greenland margin-thalassiosira kushirensis and Thalassiosira antarctica var. borealis-hydrological consequences. Marine Micropaleontology 88-89, 1-14.

Kubiszyn A.M., Piwosz K., Wiktor Jr J.M. \& Wiktor J.M. 2014. The effect of inter-annual Atlantic Water inflow variability on the planktonic protist community structure in the west Spitsbergen waters during the summer. Journal of Plankton Research 36, 1190-1203.

Locarnini R.A., Mishonov A.V., Antonov J.I., Boyer T. P., Garcia H.E., Baranova O.K., Zweng M.M., Paver C.R., Reagan J.R., Johnson D.R., Hamilton M. \& Seidov D. 2013. World Ocean atlas 2013. Vol. 1. Temperature. NOAA Atlas NESDIS 73. Silver Spring, MD: National Oceanic and Atmospheric Administration, National Environmental Satellite, Data, and Information Service, US Department of Commerce.
Makarova I.V. (ed.) 2002. The diatoms of Russia and adjacent countries: fossil and recent. Vol. 2. Issue 3. St. Petersburg: St. Petersburg University Press.

Makarova I.V., Gleser S.I., Moisseeva A.I. \& Nikolaev V.A. (Eds.). 1988. The diatoms of the USSR: fossil and recent. Vol. 2. Issue 1. Leningrad: Nauka Press.

Mann M., Zhang Z., Rutherford S., Bradley R.S., Hughes M.K., Shindell D., Ammann C., Faluvegi G. \& Ni F. 2009. Global signatures and dynamical origins of the Little Ice Age and Medieval Climate Anomaly. Science 326, 1256-1260.

Marnela M., Rudels B., Olsson K.A., Anderson L.G., Jeansson E., Torres D.J., Messias M.-J., Swift J.H. \& Watson A.J. 2008. Transports of Nordic Seas water masses and excess $\mathrm{SF}_{6}$ through Fram Strait to the Arctic Ocean. Progress in Oceanography 78, 1-11.

Matul A.G. \& Abelmann A. 2005. Pleistocene and Holocene distribution of the radiolarian Amphimelissa setosa Cleve in the North Pacific and North Atlantic: evidence for water mass movement. Deep-Sea Research II 52, 2351-2364.

Matul A.G., Khusid T.A., Mukhina V.V., Chekhovskaya M.P. \& Safarova S.A. 2007. Recent and Late Holocene environments on the southeastern shelf of the Laptev Sea as inferred from microfossil data. Oceanology 47, 80-90.

Miettinen A., Divine D., Husum K., Koç N. \& Jennings A. 2015. Exceptional ocean surface conditions on the SE Greenland shelf during the Medieval Climate Anomaly. Paleoceanography 30, 1657-1674.

Miettinen A., Koç N. \& Husum K. 2013. Appearance of the Pacific diatom Neodenticula seminae in the northern Nordic Seas-an indication of changes in Arctic sea ice and ocean circulation. Marine Micropaleontology 99, 2-7.

Miller G.H., Brigham-Grette J., Alley R.B., Anderson L., Bauch H.A., Douglas M.S.V., Edwards M.E., Elias S.A., Finney B.P., Fitzpatrick J.J., Funder S.V., Herbert T.D., Hinzman L.D., Kaufman D.S., Mac Donald G.M., Polyak L., Robock A., Serreze M.C., Smol J.P., Spielhagen R., White J.W.C., Wolfe A.P. \& Wolff E.W. 2010. Temperature and precipitation history of the Arctic. Quaternary Science Reviews 29, 1679-1715.

Morán X.A.G., López-Urrutia Á., Calvo-Díaz A. \& Li W.K. W. 2010. Increasing importance of small phytoplankton in a warmer ocean. Global Change Biology 16, 11371144.

Nilsen F., Skogseth R., Vaardal-Lunde J. \& Inall M. 2016. A simple shelf circulation model: intrusion of Atlantic Water on the West Spitsbergen Shelf. Journal of Physical Oceanography 46, 1209-1230.

Norwegian Ice Service 2017. Ice chart statistics. Norwegian Meteorological Institute. Accessed on the internet at http://polarview.met.no on 23 April 2018.

Norwegian Polar Institute 2017. Decadal average temperature and salinity in the core of the West Spitsbergen current. Environmental Monitoring of Svalbard and Jan Mayen. Accessed on the internet at http://www. mosj.no/en/climate/ocean/temperature-salinity-framstrait.html on 23 April 2018.

Nöthig E.-M., Bracher A., Engel A., Metfies K., Niehoff B., Peeken I., Bauerfeind E., Cherkasheva A., Gäbler-Schwarz S., Hardge K., Kilias E., Kraft A., Kidane Y.M., Lalande C., Piontek J., Thomisch K. \& Wurst M. 2015. Summertime plankton ecology in Fram Strait-a compilation of longand short-term observations. Polar Research 34, article no. 23349, doi: 10.3402/polar.v34.23349. 
Piquet A.M.-T., van de Poll W.H., Visser R.J.W., Wiencke C., Bolhuis H. \& Buma A.G.J. 2014. Springtime phytoplankton dynamics in Arctic Krossfjorden and Kongsfjorden (Spitsbergen) as a function of glacier proximity. Biogeosciences 11, 2263-2279.

Polyakov I.V., Timokhov L.A., Alexeev V.A., Bacon S., Dmitrenko I.A., Fortier L., Frolov I.E., Gascard J.-C., Hansen E., Ivanov V.V., Laxon S., Mauritzen C., Perovich D., Shimada K., Simmons H.L., Sokolov V.T., Steele M. \& Toole J. 2010. Arctic Ocean warming contributes to reduced polar ice cap. Journal of Physical Oceanography 40, 2743-2756.

Poulin M., Lundholm N., Bérard-Therriault L., Starr M. \& Gagnon R. 2010. Morphological and phylogenetic comparisons of Neodenticula seminae (Bacillariophyta) populations between the Subarctic Pacific and the Gulf of St. Lawrence. European Journal of Phycology 45, 127-142.

Proshkina-Lavrenko A.I., Gleser S.I., Jousé A.P., Makarova I.V. \& Sheshukova-Poretzkaya V.S. (eds.) 1974. The diatoms of the USSR: fossil and recent. Vol. I. Leningrad: Nauka Press.

Ramseier R.O., Garrity C., Bauerfeind E. \& Peinert R. 1999. Seaice impact on long-term particle flux in the Greenland Sea's Odden-Nordbukta region, 1985-1996. Journal of Geophysical Research-Oceans 104, 5329-5343.

Reid P.C., Johns D.G., Edwards M.I.N., Starr M., Poulin M. \& Snoeijs P. 2007. A biological consequence of reducing Arctic ice cover: arrival of the Pacific diatom Neodenticula seminae in the North Atlantic for the first time in 800000 years. Global Change Biology 13, 1910-1921.

Ren J., Gersonde R., Esper O. \& Sancetta C. 2014. Diatom distributions in northern North Pacific surface sediments and their relationship to modern environmental variables. Palaeogeography, Palaeoclimatology, Palaeoecology 402, 81-103.

Rey F. 2012. Declining silicate concentrations in the Norwegian and Barents seas. ICES Journal of Marine Science 69, 208-212.

Rueda G., Fietz S. \& Rosell-Melé A. 2013. Coupling of air and sea surface temperatures in the eastern Fram Strait during the last 2000 years. The Holocene 23, 692-698.

Samtleben C., Schäfer P., Andruleit H., Baumann A., Baumann K.-H., Kohly A., Matthiessen J., SchröderRitzrau A. \& 'Synpal' Working Group. 1995. Plankton in the Norwegian-greenland Sea: from living communities to sediment assemblages-an actualistic approach. Geologische Rundschau 84, 108-136.

Sancetta C. 1981. Oceanographic and ecological significance of diatoms in surface sediments of the Bering and Okhotsk seas. Deep-Sea Research 28A, 789-817.

Sancetta C. 1982. Distribution of diatom species in surface sediments of the Bering and Okhotsk seas. Micropaleontology 28, 221-257.

Schlitzer R. 2016. Ocean Data View, version 4.7.7. http://odv. awi.de.

Schlüter M., Sauter E.J., Schulz-Bull D., Balzer W. \& Suess E. 2001. Fluxes of organic carbon and biogenic silica reaching the seafloor: a comparison of high northern and southern latitudes of the Atlantic Ocean. In P. Schäfer et al. (eds.): The northern North Atlantic: a changing environment. Pp. 225-240. Berlin: Springer.

Sejrup H.P., Seppä H., McKay N.P., Kaufman D.S., Geirsdóttir Á., de Vernal A., Renssen H., Husum K., Jennings A. \& Andrews J.T. 2016. North Atlantic-fennoscandian Holocene climate trends and mechanisms. Quaternary Science Reviews 147, 365-378.
Sieger R. \& Grobe H. 2013. PanPlot 2-software to visualize profiles and time series. Helmholtz Center for Polar and Marine Research, Bremerhaven, Alfred Wegener Institute, doi: 10.1594/PANGAEA.816201.

Smol J.P. \& Stoermer E.F. (eds.) 2010. The diatoms: applications for the environmental and Earth sciences. 2nd edn. New York: Cambridge University Press.

Soltwedel T., Bauerfeind E., Bergmann M., Bracher A., Budaeva N., Busch K., Cherkasheva A., Fahl K., Grzelak K., Hasemann C., Jacob M., Kraft A., Lalande C., Metfies K., Nöthig E.-M., Meyer K., Quéric N.-V., Schewe I., Włodarska-Kowalczuk M. \& Klages M. 2016. Natural variability or anthropogenically-induced variation? Insights from 15 years of multidisciplinary observations at the Arctic marine LTER site HAUSGARTEN. Ecological Indicators 65, 89-102.

Spielhagen R.F., Werner K., Sørensen S.A., Zamelczyk K., Kandiano E., Budeus G., Husum K., Marchitto T.M. \& Hald M. 2011. Enhanced modern heat transfer to the Arctic by warm Atlantic Water. Science 331, 450-453.

Stabell B. 1987. The diatom flora in the Fram Strait. A comparison with the Pleistocene/Holocene boundary flora in the Norwegian Sea. Polar Research 5, 321-322.

Starr M., St-Amand L. \& Bérard-Therriault L. 2002. State of phytoplankton in the Estuary and Gulf of St. Lawrence during 2001. Canadian Science Advisory Secretariat Research Document 2002/067. Quebec: Fisheries and Oceans Canada.

Strelnikova N.I. \& Tsoy I.B. (eds.) 2008. The diatoms of Russia and adjacent countries: fossil and recent. Vol. II. Issue 5. St. Petersburg: St. Petersburg University Press.

Sun X., Humborg C., Mörth C.-M. \& Brüchert V. 2017. Early diagenesis of silica in the Arctic Ocean sediments inferred by porewater stable silicon isotopes. Poster presented at the Goldschmidt 2017 conference, 13-18 August, Paris. Goldschmidt Abstracts 3833.

Talley L.D., Pickard G.L., Emery W.J. \& Swift J.H. 2011. Descriptive physical oceanography: an introduction. 6th edn. Boston: Elsevier.

Torres-Valdés S., Tsubouchi T., Bacon S., NaveiraGarabato A.C., Sanders R., McLaughlin F.A., Petrie B., Kattner G., Azetsu-Scott K. \& Whitledge T.E. 2013. Export of nutrients from the Arctic Ocean. Journal of Geophysical Research-Oceans 118, 1625-1644.

Tung K.-K. \& Zhou J. 2013. Using data to attribute episodes of warming and cooling in instrumental records. Proceedings of the National Academy of Sciences of the USA 110, 2058-2063.

Tyrrell T., \& Merico A. 2004. Emiliania huxleyi: bloom observations and the conditions that induce them. In H.R. Thierstein \& J.R. Young (eds.): Coccolithophores: From molecular processes to global impact. Pp. 75-97. Berlin: Springer.

Villareal T., Joseph L., Brzezinski M.A., Shipe R.F., Lipschultz F. \& Altabet M.A. 1999. Biological and chemical characteristics of the giant diatom Ethmodiscus (Bacillariophyceae) in the Central North Pacific Gyre. Journal of Phycology 35, 896-902.

Volkman J.K., Eglinton G., Corner E.D.S. \& Sargent J.R. 1980. Novel unsaturated straight-chain $\mathrm{C}_{37}-\mathrm{c}_{39}$ methyl and ethyl ketones in marine sediments and a coccolithophore Emiliania huxleyi. In A.G. Douglas \& J.R. Maxwell (eds.): Advances in organic geochemistry 1979. Pp. 219227. Oxford: Pergamon Press.

von Quillfeldt C.H., Ambrose W.G. Jr. \& Clough L.M. 2003. High number of diatom species in first year ice from the Chukchi Sea. Polar Biology 26, 806-818. 
Weckström K., Miettinen A., Caissie B., Pearce C., Ellegaard M., Krawczyk D. \& Witkowski A. 2014. Sea surface temperatures in Disko Bay during the Little Ice Age-caution needs to be exercised before assigning Thalassiosira kushirensis resting spore as a warm-water indicator in palaeoceanographic studies. Quaternary Science Reviews 101, 234-237.

Werner K., Frank M., Teschner C., Müller J. \& Spielhagen R.F. 2013. Neoglacial change in deep water exchange and increase of sea-ice transport through eastern Fram Strait: evidence from radiogenic isotopes. Quaternary Science Reviews 92, 190-207.

Werner K., Spielhagen R.F., Bauch D., Hass H.C., Kandiano E. \& Zamelczyk K. 2011. Atlantic Water advection to the eastern Fram Strait-multiproxy evidence for late Holocene variability. Palaeogeography, Palaeoclimatology, Palaeoecology 308, 264-276.
Zamelczyk K., Rasmussen T.L., Husum K. \& Hald M. 2013. Marine calcium carbonate preservation vs. climate change over the last two millennia in the Fram Strait: implications for planktic foraminiferal paleostudies. Marine Micropaleontology 98, 14-27.

Zielinski U., Gersonde R., Sieger R. \& Fütterer D.K. 1998. Quaternary surface water temperature estimations: calibration of a diatom transfer function for the Southern Ocean. Paleoceanography 13, 365-383.

Zweng M.M., Reagan J.R., Antonov J.I., Locarnini R.A., Mishonov A.V., Boyer T.P., Garcia H.E., Baranova O.K., Johnson D.R., Seidov D. \& Biddle M.M. 2013. World Ocean atlas 2013. Vol. 2. Salinity. NOAA Atlas NESDIS 74. Silver Spring, MD: National Oceanic and Atmospheric Administration, National Environmental Satellite, Data, and Information Service, US Department of Commerce. 